Journal of Engineering and Applied Sciences 15 (3): 861-864, 2020

ISSN: 1816-949X

(C) Medwell Journals, 2020

\title{
Analysis of Land Physical Change, Land Use and Value of Soil Erosion: Case Study of Tawaeli Watershed, Palu, Indonesia
}

\author{
Ramlan, Salapu Pagiu, Yosep S. Pata'Dungan and Abd. Rahman \\ Faculty of Agriculture, Tadulako Universitas, City of Palu, Indonesia
}

\begin{abstract}
This study aimed to examine land physical change against the erodibility of soil erosion. This study is a form of land use survey. It was performed in the Taweli watershed in the city of Palu. Sample was randomly taken. Research variables were rainfall erosivity, physical characteristics and value of soil erodibility, Length and Slope (LS), vegetation factor and soil management. The value of erosion was calculated based on USLE (Universal Soil Loss Equation) method. Study result revealed that the forest had the value of soil erosion of 0.18- 2.15 ton $^{-1} \mathrm{year}^{-1}$ that categorized as very low erosion hazard level. Mixed farming land had the value of soil erosion of 6.97-29.29 ton ha ${ }^{-1}$ year ${ }^{-1}$ that categorized as low, shrubs was categorized into average to heavy erosion hazardous level of 89.44-1687.64 ton $^{-1} \mathrm{year}^{-1}$ and the primary forests had value of erosion of 1.68, 9.80 and 19.85 ton ha $^{-1}$ year-1 ${ }^{-1}$, respectively which categorized as very low. Therefore, it can be inferred that land of shrubs have high value of erosion compared to the land use for forest and mixed farming agriculture.
\end{abstract}

Key words: Land physic, land use, value of erosion, categorized, shrubs, high value

\section{INTRODUCTION}

Changes in land use can be attributed to the increasing number of population and reduced and limited land resource availability (Kusrini et al., 2016). The growing number of population has led to massive exploitation of natural resources such as the deforestation activities in the upstream watersheds (Senawi, 2009). The magnitude of soil erosion can be caused by 2 main factors, namely natural factors and human activities (Guo et al., 2018). Natural factor can be the soil resilience whereas human activities comprise the efforts to opening new land and the top soil peeled off due to cropping and farming activities which are not in accordance with the soil conservation rules or development activities that are destructive to the land physic like road construction at the area with big slope.

Soil erodibility index shows the soil resilience against erosion, namely particle retention to detachment and soil displacement due to rainfall kinetic energy (Cassol et al., 2018). High organic matter content will lead to high erodibility value (Santoso et al., 2014). Lands for forests, monoculture farming and multiple cropping at the same slope will have different erosion level. It is caused by, among others, vegetation found in each different land (Arifin, 2010). Slope, permeability, texture and soil structures influence the magnitude of the soil erosion as well (Ashari, 2013).

The changes in land physical characteristics occur due to forest conversion into agriculture purposes. Farm lands are more susceptible to land damages compared to the forest lands. This can be attributed to the existence of vegetation or plants as rain backstop or the low organic matter from the plant brown wastes where the rainfalls will be easier in breaking the soil granules. This study was aimed to examine the land physical changes towards soil erosion.

\section{MATERIALS AND METHODS}

This study is a quantitative study held in the Taweli watershed in the city of Palu in 2018. The study variables were rainfall erosivity, physical characteristics and value of soil erodibility, Length and Slope (LS), vegetation factor and soil management as well as the value of erosion.

Data sources were primary and secondary ones. Primary data comprises direct measurement done by the researchers, i.e., physical characteristics and the value of soil erodibility by taking the sample of undisturbed and disturbed soils. Undisturbed soil sample is used to analyze the soil physical characters consisting of bulk density, soil structures and soil permeability while the disturbed soil sample is used to analyze the soil textures and organic matter contents. Moreover, the researchers also measure the length and slope, observation of plant commodity and their management. Data on rainfall erosivity was collected from climatology data, namely data rainfall data in the city of Palu.

Analysis of the value of soil erosion used the equation of USLE (Universal Soil Loss Equation) in which the magnitude of soil erosion (loss) is the function of rainfall erosivity, soil erodibility, length and slope as well as vegetation factor and land management:

Corresponding Author: Ramlan, Faculty of Agriculture, Tadulako University, City of Palu, Indonesia Mobile Phone +62 811-452-460 


\section{$\mathrm{A}=\mathrm{R} \mathrm{K} \mathrm{L} \mathrm{S} \mathrm{C} \mathrm{P}$}

Where:
A : Amount of lost soil (ton ha ${ }^{-1}$ year $^{-1}$ )
$\mathrm{R}$ : Average annual rainfall erosivity $(\mathrm{cm})$
$\mathrm{K}$ : Soil erodibility index
LS : Length and Slope index

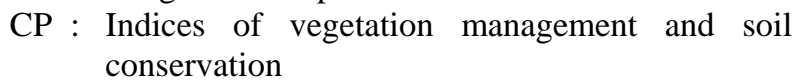

\section{RESULTS AND DISCUSSION}

Rainfall erosivity (R): Figure 1 shows the annual erosivity value in the study location of 13002 thus, during 5 years the average rainfall erosivity index for that area was $1182.29 \mathrm{~mm}$ year $^{-1}$.

Physical characteristic and value of erodibility (K): Table 1 shows that mixed cropping farmlands had the lowest organic matter, namely $1.14 \%$ whereas primary forest was the study location that had the highest organic matter, i.e., 5.21\%. Soil of the shrubs had lower coarse sand compared to the flattened shrub of $28.21 \%$ and lower clay of $5.7 \%$ as well as higher dust and fine sand of $60.6 \%$.
Soil erodibility (K): Table 2 shows that the highest erodibility value was found in the primary forest and shrubs. Soil erodibility $(K)$ is the sensitivity of soil erosion that shows whether the soil is easily eroded or not.

Length and Slope (LS): Table 3 shows that the percentage of slope for the shrubs was $20 \%$ and for primary forest was 20\%. Meanwhile for the multiple cropping, the maximum slope percentage was $12 \%$.

Vegetation factor and soil management: Table 4 shows that there were not any soil management activities in the study location. And the highest vegetation factor found in the multiple cropping land and shrubs.

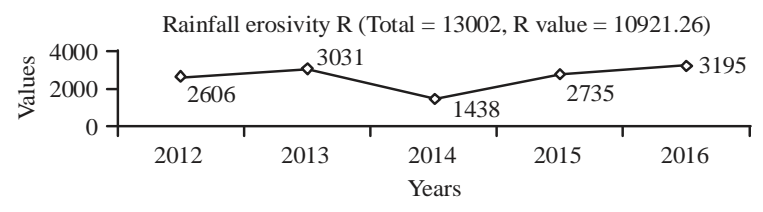

Fig. 1: Annual erosivity index

Table 1: Soil physical characteristics in each of land uses

\begin{tabular}{|c|c|c|c|c|c|c|c|c|}
\hline \multirow[b]{2}{*}{ Parameters } & \multicolumn{8}{|c|}{ Type of land } \\
\hline & a & b & c & $\mathrm{d}$ & e & $\mathrm{f}$ & g & $\mathrm{h}$ \\
\hline $\mathrm{BO}(\%)$ & 1.84 & 1.14 & 3.26 & 3.83 & 1.85 & 2.25 & 3.47 & 5.21 \\
\hline Coarse sand (\%) & 19.08 & 22.65 & 28.21 & 9.49 & 10.29 & 20.44 & 13.09 & 12.22 \\
\hline Fine sand $(\%)$ & 35.42 & 42.05 & 52.39 & 17.61 & 19.11 & 37.96 & 24.31 & 22.68 \\
\hline Dust (\%) & 28.70 & 21.00 & 13.60 & 60.60 & 55.40 & 27.80 & 51.10 & 53.10 \\
\hline Clay (\%) & 16.80 & 14.30 & 5.70 & 12.36 & 19.11 & 13.70 & 11.40 & 12.00 \\
\hline Soil structure (mm) & 3.00 & 3.00 & 4.00 & 3.00 & 4.00 & 3.00 & 4.00 & 4.00 \\
\hline Permeability $\left(\mathrm{cm} \mathrm{h}^{-1}\right)$ & 6.78 & 8.21 & 3.29 & 6.68 & 2.11 & 9.34 & 4.43 & 4.43 \\
\hline
\end{tabular}

Table 2: Value of erodibility (K) based on land use

\begin{tabular}{lcc}
\hline Land use & K value & Erodibility level \\
\hline Multiple cropping & 0.360 & Quite high \\
Multiple cropping & 0.332 & Quite high \\
Shrub & 0.308 & Medium \\
Shrub & 0.442 & High \\
Shrub & 0.519 & High \\
Primary forest & 0.347 & Quite high \\
Primary forest & 0.445 & High \\
Primary forest & 0.366 & Quite high \\
\hline
\end{tabular}

Table 3: Length and slope value based on land use

\begin{tabular}{lccc}
\hline Land use & Slope (\%) & Length (m) & LS index \\
\hline Multiple cropping & 4 & 44.27 & 0.089 \\
Multiple cropping & 12 & 65.44 & 0.404 \\
Shrub & 4 & 44.27 & 0.089 \\
Shrub & 12 & 65.44 & 0.404 \\
Shrub & 20 & 64.16 & 0.992 \\
Primary forest & 4 & 44.27 & 0.089 \\
Primary forest & 12 & 65.44 & 0.404 \\
Primary forest & 20 & 64.16 & 0.992 \\
\hline
\end{tabular}


J. Eng. Applied Sci., 15 (3): 861-864, 2020

Table 4: Value of vegetation factor and land management

\begin{tabular}{lccc}
\hline Land use & Vegetation $(\mathrm{C})$ & Soil management $(\mathrm{P})$ & $\mathrm{C} \times \mathrm{p}$-value \\
\hline Multiple cropping & 0.200 & - & 0.200 \\
Multiple cropping & 0.200 & - & 0.200 \\
Shrub & 0.300 & - & 0.300 \\
Shrub & 0.300 & - & 0.300 \\
Shrub & 0.300 & - & 0.300 \\
Primary forest & 0.005 & - & 0.005 \\
Primary forest & 0.005 & - & 0.005 \\
Primary forest & 0.005 & 0.005 \\
\hline
\end{tabular}

Table 5: Value of erosion and erosion hazardous level based on land use

\begin{tabular}{lllllrl} 
Land use & $\mathrm{R}$ & $\mathrm{K}$ & $\mathrm{LS}$ & $\mathrm{CP}$ & ${\text { Value of erosion }\left(\text { ton }^{-1} \mathrm{year}^{-1}\right)}^{\text {Erosion hazardous level }}$ \\
\hline Multiple cropping & 10921.26 & 0.360 & 0.089 & 0.200 & 6.97 & Very low \\
Multiple cropping & 10921.26 & 0.332 & 0.404 & 0.200 & 29.29 & Low \\
Shrub & 10921.26 & 0.308 & 0.089 & 0.300 & 89.44 & Medium \\
Shrub & 10921.26 & 0.442 & 0.404 & 0.300 & 583.22 & Very high \\
Shrub & 10921.26 & 0.519 & 0.992 & 0.300 & 1687.64 & Very high \\
Primary forest & 10921.26 & 0.347 & 0.089 & 0.005 & 1.68 & Very low \\
Primary forest & 10921.26 & 0.445 & 0.404 & 0.005 & 9.80 & Very low \\
Primary forest & 10921.26 & 0.366 & 0.992 & 0.005 & 19.85 & Very low \\
\hline
\end{tabular}

Value of erosion: Table 5 shows that the erosion hazardous level was found in the shrubs whereas low category can be found in multiple cropping and very low in the primary forest.

Soil with sufficient organic matter content will make the soil structure becoming steadier thus resistant to erosion. Soil with $<2 \%$ organic matter content is generally susceptible to erosion (Andriani, 2017). Organic matter in the soil serves as adhesive (cementing agent) in the formation and stabilization of soil aggregate, thereby they will not be easily damaged or broken by the hit of rain granules (Zhao et al., 2014).

Soil texture has influence on the soil erodibility, namely the coarser the soil texture, the higher $\mathrm{K}$ value is therefore, more susceptible to erosion (Belasri et al., 2017). On the contrary, the finer the soil texture, the lower $\mathrm{K}$ value is which means that the soil is more resistant to erosion. In addition to soil texture, the land use of multiple cropping agriculture and the ways of farming, as well as land use intensity all have such a great influence on the value of soil erodibility (Jeloudar et al., 2018). Moreover, changes in land use have caused the reduced of organic matter content in the soil that has been accelerated by decomposition process, thereby the direct collision of rain water on the ground is able to damage the soil aggregate and pore system (Andriani, 2017; Emadi et al., 2009).

The study results reveal that the land use in the watershed area has high erosion hazardous level, especially for the shrubs. Meanwhile, multiple cropping and primary forest have low erosion hazardous level. The area covered with shrubs can be conserved by carrying out contour-based planting and strip cropping (Pasaribu et al., 2018). Soil conservation technique can be done by means of growing seasonal or annual crops with close density among vegetation, so that, that will prevent the surface runoff at the base of the shrubs since vegetation in closer density will forestall the the runoff of rainfall on the ground surface (Pasaribu et al., 2018). Surface runoff on the steep slope, the one that triggers significant erosion can be overcome by counterbalancing it with high vertical vegetation upright and horizontal vegetation cover the soil, hence, they are able to hamper the pace of water runoff (Lathifah and Yunianto, 2013).

\section{CONCLUSION}

The shrub land area has high value of erosion influence compared to the land uses for forest and multiple cropping purposes. The forest area has value of soil erosion of $0.18-2.15$ ton $^{-1} \mathrm{year}^{-1}$, categorized as very low in erosion hazardous level criteria. The multiple cropping land has value of soil erosion of 6.97-29.29 ton $\mathrm{ha}^{-1}$ year $^{-1}$, classified as very low. The shrub area is sorted as medium to high in erosion hazardous level of 89.44-1687.64 ton $\mathrm{ha}^{-1} \mathrm{year}^{-1}$. As to value of erosion, three primary forest have their value of 1.68, 9.80 and 19.85 ton ha $^{-1}$ year $^{-1}$, respectively, categorized as very low.

\section{REFERENCES}

Andriani, V., 2017. [Analysis of Soil Erodibility in Different Types of Land and Land Use: Case Study of Cikapundung Sub-watershed in Bandung]. Department of Land Science and Resources, Bogor Agricultural Institute, Indonesia. (In Indonesian) https://translate.google.com/translate?hl=en\&sl=id \&u=https://repository.ipb.ac.id/handle/123456789/8 3572\&prev=search 
Ashari, A., 2013. [Erodibility level study of some types of lands in BATURAGUNG Mountain Putat Village and Nglanggeran District, Patuk District, Gunungkidul District (In Indonesian)]. Informasi, 14: 15-31.

Belasri, A., A. Lakhouili and O.I. Halima, 2017. Soil erodibility mapping and its correlation with soil properties of Oued El Makhazine watershed, Morocco. J. Mater. Environ. Sci., 2: 3208-3215.

Cassol, E.A., T.S.D. Silva, F.L.F. Eltz and R. Levien, 2018. Soil erodibility under natural rainfall conditions as the $\mathrm{K}$ factor of the Universal Soil Loss Equation and application of the nomograph for a subtropical Ultisol. Rev. Bras. Cienc. Solo, Vol. 42, 10.1590/18069657rbcs20170262

Emadi, M., M. Baghernejad and H.R. Memarian, 2009. Effect of land-use change on soil fertility characteristics within water-stable aggregates of two cultivated soils in northern Iran. Land Policy, 26: 452-457.
Guo, S., Z. Zhu and L. Lyu, 2018. Effects of climate change and human activities on soil erosion in the Xihe River Basin, China. Water, Vol. 10, No. 8. 10.3390/w10081085

Jeloudar, F.T., M. Ghajar Sepanlou and M. Emadi, 2018. Impact of land use change on soil erodibility. Global J. Environ. Sci. Manage., 4: 59-70.

Lathifah, D.H. and T. Yunianto, 2013. [Relationship between the function of vegetation cover and watershed erosion rate of Kulonprogo District]. J. Bumi Indonesia, Vol. 2,

Pasaribu, P.H.P., A. Rauf and B. Slamet, 2018. [Study of erosion hazard levels for soil conservation directives in different types of land use in Merdeka District, Karo District (In Indonesian)]. J. Geogr., 10: 279-284.

Zhao, W., S.L. Walker, Q. Huang and P. Cai, 2014. Adhesion of bacterial pathogens to soil colloidal particles: Influences of cell type, natural organic matter and solution chemistry. Water Res., 53: 35-46. 